\title{
Republicans want 'junk science', says Gore
}

Baltimore. Vice President $\mathrm{Al}$ Gore this week sought to bring US science policy into the lengthy campaign for next November's presidential and congressional elections with a fiery denunciation of Republican science policy which, he said, had "the wisdom of a potted plant".

Gore said that Republicans were proposing "the sharpest cuts in non-defense research since World War II" and that "on question after question, they say that "we don't know enough to act, and we don't want to know"'. He added that recent statements from Republican congressmen "ought to send shivers up our spines" and suggested "a deeper disregard for science itself, a taste for junk science, and a belief that science is just another rhetorical tool to be twisted" for political ends.

Speaking at the annual meeting of the American Association for the Advancement of Science (AAAS) in Baltimore, Maryland, Gore sought to draw a clear line between Democrat and Republican visions for science. "At the end of this century we have a choice of two paths," he said. The Republican one was "a direct descendant of the society that insisted that the Earth was flat" in which research in key areas was neglected and "the houses of knowledge fell into disrepair". In contrast, the Democratic administration's path was "dotted with investments

that open the door to education for all of our people," he said.

Gore's speech to the AAAS was the first of three major science policy addresses he was planning this week. The others were to be made at a computer industry meeting in

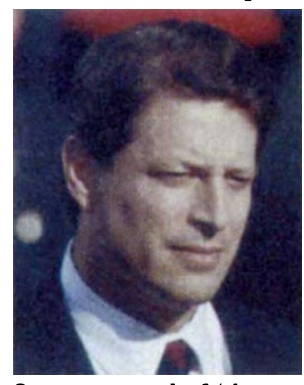

Gore: warned of 'deep disregard for science'.
Crystal City, Virginia, and at the fiftieth birthday celebrations of the first US computer system in Philadelphia, Pennsylvania.

The speeches come in what is effectively the opening week of the 1996 election campaign, with President Bill Clinton in Iowa campaigning against a still-to-be-selected Republican opponent, while congressmen return to their districts to prepare for elections in which the Democrats have an outside chance of regaining control of the House of Representatives.

One case that Gore cited as an example of Republican "disregard of science" was a comment made by Representative Tom DeLay (Republican, Texas), to the effect that the ban on CFCs was scientifically debatable and "the result of a media scare". Another was the memorable description of global warming as "liberal clap-trap" by Representative Dana Rohrabacher (Republican, California), and a third example was a statement by an Oklahoma congressman that an outbreak of Cryptosporidium from a contaminated water supply was "helpful for finding those who are immune-compromised".

The vice president praised Jack Gibbons, Clinton's science adviser, as "the most influential science advisor the White House has seen for a generation", and, for the first time, sought to list the science policy achievements of the administration's first term. These included improved protection of intellectual property rights, increased funding for the major science agencies, more environmental research and better environmental regulation. The list excluded Clinton's technology programmes, which are now fighting for survival.

In the 1992 campaign, Gore had some success in associating the Clinton campaign with technology in general, and the 'information superhighway' in particular. This week's speeches suggest that Gore sees an opening for Clinton and himself to present themselves as the protectors of science against barbaric Republican cuts - a theme that will fit in with the broader education and environment planks of the Clinton presidential campaign.

Colin Macilwain

\section{Health secretary backs AIDS office's budget authority}

Washington. Donna Shalala, the US Secretary of Health and Human Services (HHS), insisted last week that, despite pressure from Republicans in Congress and a recent decision by the National Institutes of Health (NIH), the NIH's Office of AIDS Research (OAR) will not lose control of $\$ 1.4$ billion a year in research funding.

Addressing the annual meeting of the National Association of Science Writers in Baltimore, Maryland, Shalala said: "Make no mistake about it: the president and $I$ are absolutely committed to maintaining a strong Office of AIDS Research — with its budget authority kept completely intact."

NIH director Harold Varmus echoed that commitment on Monday (12 February), but said there was no question of 1996 funding being routed through the OAR. "This year, I think it's done," he said. "But we will be making a very strong case for [routing money through the OAR in the] budget for [1997]". Varmus added that he was "strongly in support of the OAR and what [director] Bill Paul is doing".

Paul said that the decision to fund institutes directly in 1996 made little difference to the power of his office. "The great authority of the OAR lies in its responsibility to develop a comprehensive plan for AIDS research and, secondly, to determine what sums of money the individual institutes will require to carry out the AIDS research activities that the OAR has approved," he said.

The OAR develops budget figures for AIDS spending by each NIH institute and centre early each year. The circumvention of the OAR means that the sums recommended for each insitute, once appropriated by Congress, cannot be readjusted by the OAR, as they flow from the US Treasury to the institutes.

Various institute directors at NIH are known to resent the role of the OAR which, in 1996 , is charged with distributing $\$ 1.4$ billion allocated to AIDS research, 11.8 per cent of the NIH's \$11.9-billion budget. But Shalala insisted that the 1993 law giving OAR authority to oversee all AIDS research at NIH would continue to be followed.

She said that the law should take precedence over a stop-gap spending measure passed in January funding NIH up to the end of the fiscal year. This has been interpreted by NIH officials, HHS lawyers and lawyers in the administration's Office of Management and Budget as directing that the OAR should be bypassed, and that research funds for 1996 should be channelled directly to the NIH's 24 institutes and centres (see Nature 379, 475: 1996). The NIH says that the decision was taken in consultation with its lawyers.

Shalala claimed later that any scientists and administrators lobbying Congress to circumvent the OAR would, at least in theory, be putting their jobs at risk. "If I catch anyone, I'll fire them," she threatened. "But I won't catch them," she added.

On the same day (9 February), Representative John Porter (Republican, Illinois) insisted that the NIH's decision at the end of last month to channel AIDS money directly to its institutes was entirely "mechanical", and that it would have no impact on the political authority of the 33member OAR.

But this interpretation is challenged by many AIDS activists and researchers, who say that the move would undermine the power of the OAR. "We don't want somebody [at the head of OAR] just saying 'it would be nice if you'd study this,"' says Gregg Gonsalves, policy director of the Treatment Action Group, an AIDS group based in New York. "We don't want [Paul] to be the king of AIDS research, [but we do] want him to be the prime minister," he said. Meredith Wadman 